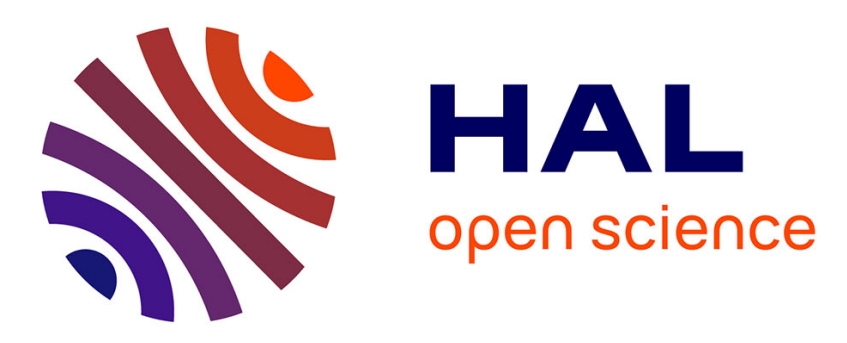

\title{
Indentor-corner tectonics in the Yakutat-St. Elias collision constrained by GPS
}

\author{
Anaïs Marechal, Stephane Mazzotti, Julie L. Elliott, Jeffrey T. Freymueller,
} Michael Schmidt

\section{- To cite this version:}

Anaïs Marechal, Stephane Mazzotti, Julie L. Elliott, Jeffrey T. Freymueller, Michael Schmidt. Indentor-corner tectonics in the Yakutat-St. Elias collision constrained by GPS. Journal of Geophysical Research, 2015, 120 (5), pp.3897-3908. 10.1002/2014JB011842 . hal-01243510

\author{
HAL Id: hal-01243510 \\ https://hal.science/hal-01243510
}

Submitted on 11 May 2021

HAL is a multi-disciplinary open access archive for the deposit and dissemination of scientific research documents, whether they are published or not. The documents may come from teaching and research institutions in France or abroad, or from public or private research centers.
L'archive ouverte pluridisciplinaire HAL, est destinée au dépôt et à la diffusion de documents scientifiques de niveau recherche, publiés ou non, émanant des établissements d'enseignement et de recherche français ou étrangers, des laboratoires publics ou privés. 


\section{Journal of Geophysical Research: Solid Earth}

\section{RESEARCH ARTICLE \\ 10.1002/2014JB011842 \\ Indentor-corner tectonics in the Yakutat-St. Elias collision constrained by GPS}

Key Points:

- New data define active tectonics in Yakutat-St. Elias collision zone

- GPS constraints on collision syntax tectonics and strain distribution

- GPS constraints on continental lithosphere response to active collision

Supporting Information:

- Texts S1-S3, Table S1, and Figures S1-S4

- Data Set S1

Correspondence to:

A. Marechal,

anais.marechal@gm.univ-montp2.fr

\section{Citation:}

Marechal, A., S. Mazzotti, J. L. Elliott, J. T. Freymueller, and M. Schmidt (2015), Indentor-corner tectonics in the Yakutat-St. Elias collision constrained by GPS, J. Geophys. Res. Solid Earth, 120, 3897-3908, doi:10.1002/2014JB011842.

Received 18 DEC 2014 Accepted 27 APR 2015 Accepted article online 30 APR 2015 Published online 22 MAY 2015

C2015. American Geophysical Union. All Rights Reserved.

\author{
Anaïs Marechal ${ }^{1}$, Stephane Mazzotti ${ }^{1,2}$, Julie L. Elliott ${ }^{3}$, Jeffrey T. Freymueller ${ }^{4}$, and Michael Schmidt ${ }^{5}$ \\ ${ }^{1}$ Géosciences Montpellier, UMR 5243, Université Montpellier 2, Montpellier, France, ${ }^{2}$ School of Earth and Ocean Sciences, \\ University of Victoria, Victoria, British Columbia, Canada, ${ }^{3}$ Earth, Atmospheric, and Planetary Sciences, Purdue University, \\ West Lafayette, Indiana, USA, ${ }^{4}$ Geophysical Institute, University of Alaska Fairbanks, Fairbanks, Alaska, USA, ${ }^{5}$ Arctic Institute \\ of North America, University of Calgary, Calgary, Alberta, Canada
}

Abstract The Yakutat-St. Elias collision in SE Alaska and adjacent Canada represents a prime example of present-day tectonics associated with an indentor corner. Its eastern syntaxis is marked by high exhumation, a sharp structural bend, and strain concentration at the transition from shortening to oblique transpression. Here we present GPS velocity and strain rate fields that cover the syntaxis, including 11 new stations in the core of the St. Elias Mountains. These data are corrected for transient deformation (glacial isostatic adjustment and postseismic and interseismic loading) to produce residual velocities and strain rates representative of long-term tectonics. The main features of these velocity and strain rate fields are a peak in strain rates (strain knot) in the syntaxis at the junction between the main fault systems and a rapid rotation from convergence-parallel to convergence-normal orientations of the velocities and shortening axes around the syntaxis, leading to shortening across the southern Denali Fault. These features are consistent with the strain and tectonic patterns expected near an indentor corner at the transition from shortening to transpression, with a combination of diffuse and localized deformation. The GPS velocities and strain rates show diffuse deformation around the syntaxis, from pure convergence-parallel shortening in the orogenic wedge to oblique extension that accommodates the strain rotation at the front of the syntaxis. This indentor-corner model also results in a near-zero strike-slip rate on the southern Denali Fault and shows no clear evidence for a throughgoing fault hypothesized to link the Fairweather and Totschunda Faults.

\section{Introduction}

Orogen syntaxes are the loci of complex, laterally varying tectonics, where the relative plate motion is partitioned onto a variety of faults associated with significant structure rotations, high strain concentration, and rapid uplift [Holt et al., 1991; Shen et al., 2005; Rosenberg et al., 2007; Spotila and Berger, 2010]. The characteristics and evolution of these syntaxes strongly depend on the tectonic boundary conditions, upper plate rheological and structural complexities, and climate-tectonics interactions [Zeitler et al., 2001; Koons et al., 2010]. The eastern syntaxis of the St. Elias orogen, associated with the Yakutat collision in SE Alaska and SW Yukon (Figure 1), is a prime example of such a system, with some of the highest peaks, steepest relief, and most abundant crustal seismicity in North America. New studies conducted over the last decade, in part within the St. Elias Erosion and Tectonics Project [Pavlis et al., 2014], highlight the impact of the Yakutat oblique collision on local and far-field tectonics as well as associated debates on activity of new versus inherited structures [Chapman et al., 2012; Doser, 2014] or strain transfer to the cordillera interior [Mazzotti et al., 2008; Finzel et al., 2014].

Addressing the complex issue of strain localization and partitioning requires a robust description of the present-day kinematics in the orogen. In this study, we present new GPS velocity and strain rate fields from a network of campaign and continuous GPS stations that cover the eastern syntaxis of the Yakutat collision in the Chugach and St. Elias Mountains (Figure 2). Data from 12 new campaign stations located in the core of the St. Elias Mountains complement existing campaign and continuous stations to the west and southeast [Leonard et al., 2007; Elliott et al., 2010, 2013]. This new data set highlights the surface kinematics at the transition between shortening to the west and dextral transpression to the southeast. In particular, one of the main results of our strain rate analysis is the partitioning of deformation around the syntaxis, i.e., localized in a strain knot and on strike-slip faults, and diffuse deformation through the orogen from shortening to oblique extension due to lateral escape. 


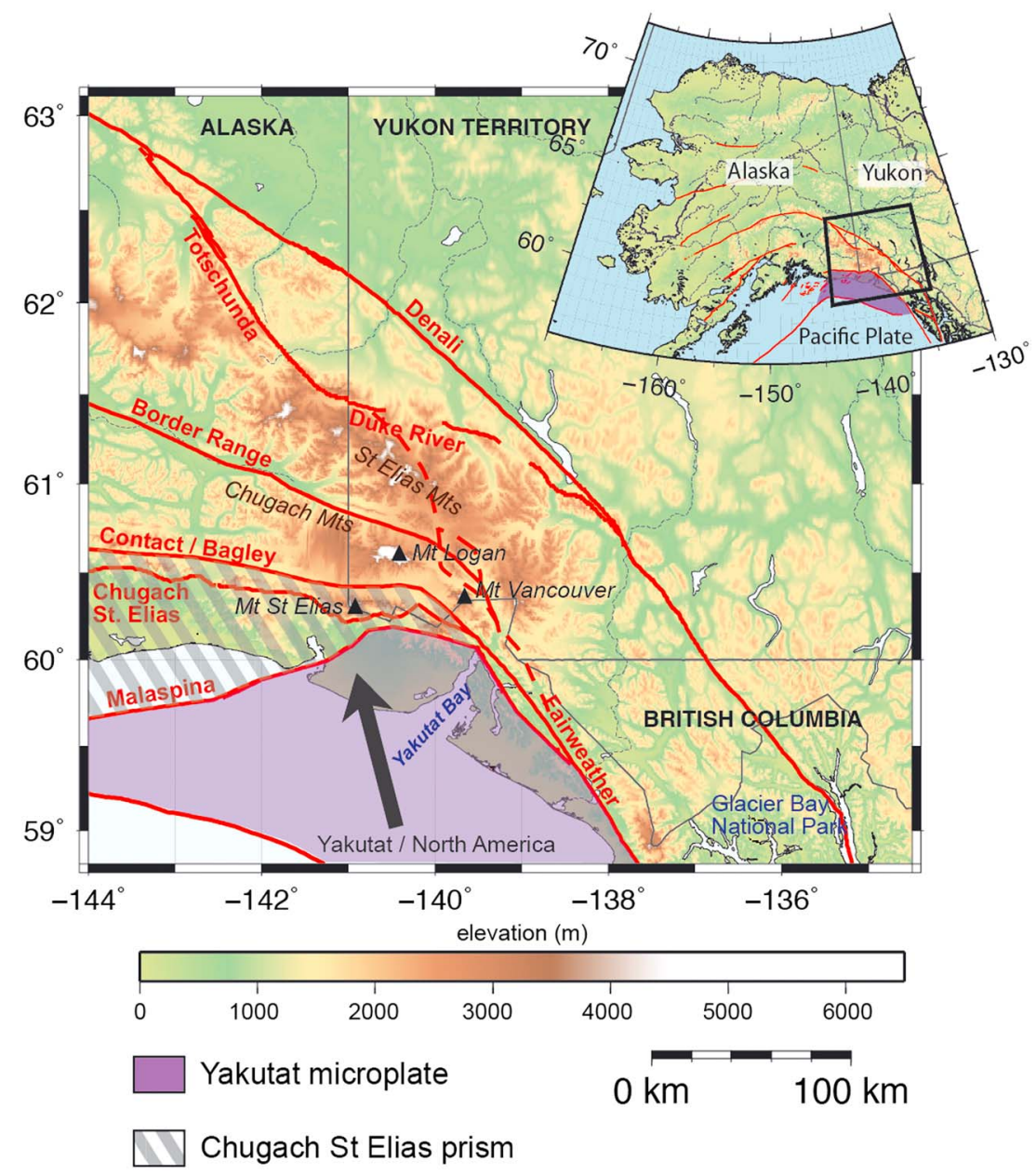

Figure 1. Topography and tectonics of the Yakutat-St. Elias collision. Red lines are inherited faults and fault systems. Dashed red line shows the hypothetical location of the Connector Fault from Spotila and Berger [2010]. The black arrow shows the Yakutat/North America (YK/NA) motion (50.3 mm/a [Elliott et al., 2010]).

(a)

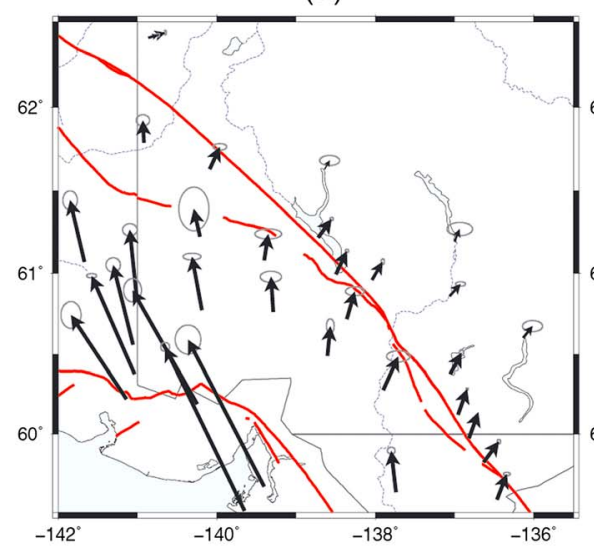

(b)

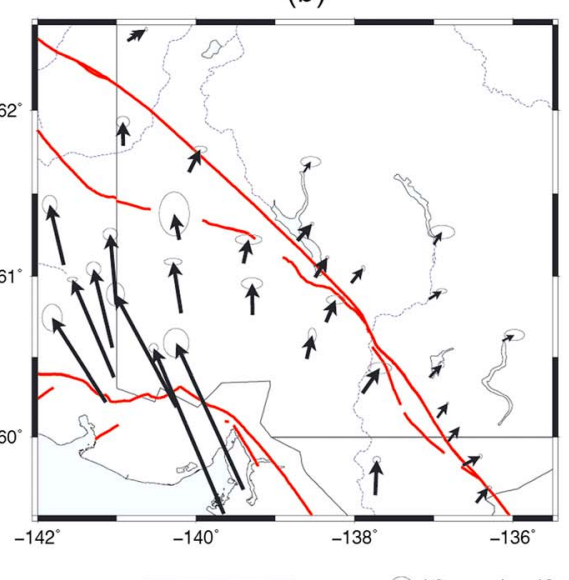

(c)

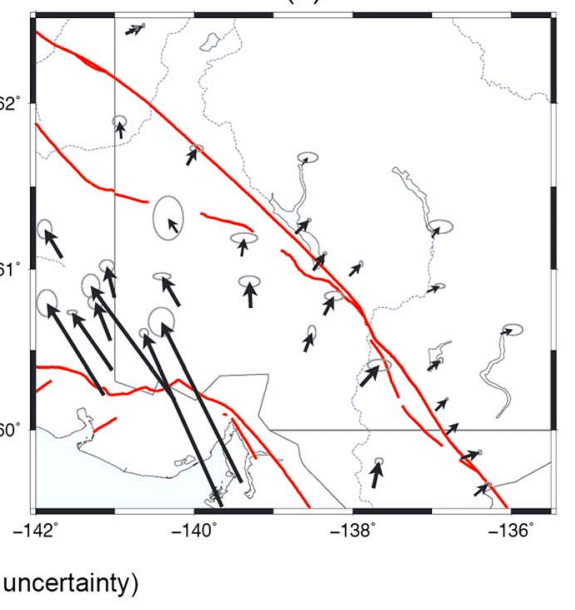

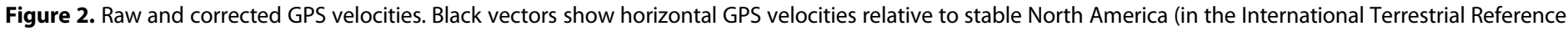

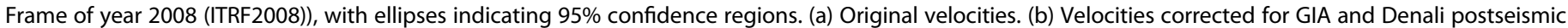
transients. (c) Velocities corrected for GIA, Denali postseismic, and main faults interseismic transients. 


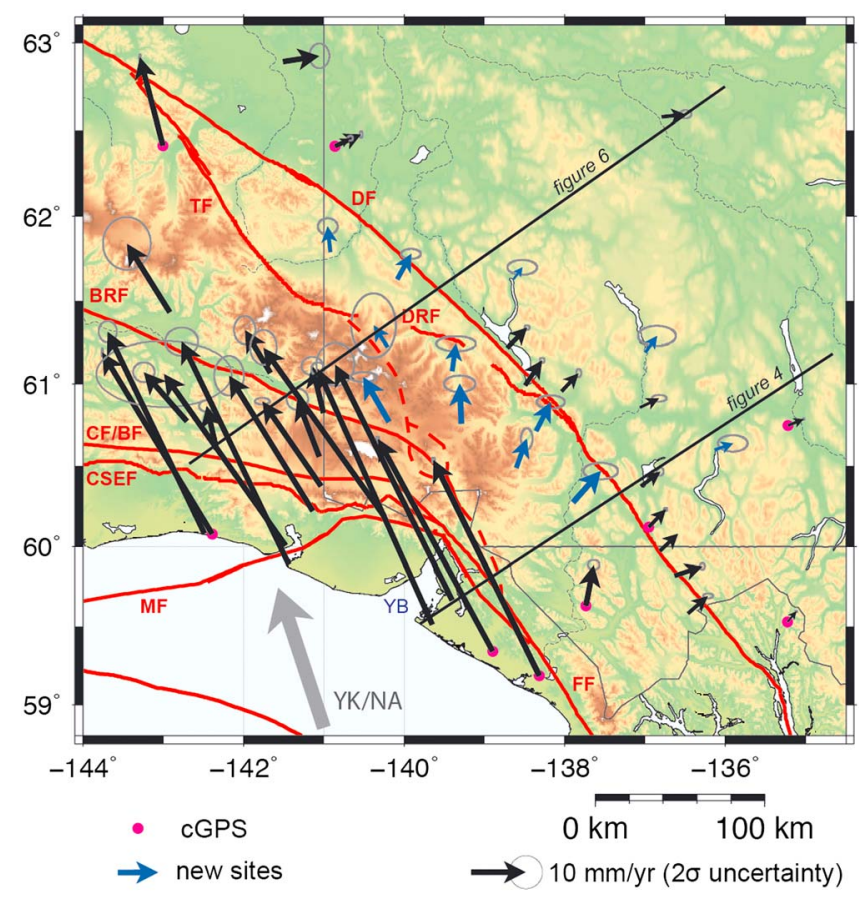

Figure 3. St. Elias residual GPS velocity field. Black vectors show horizontal GPS velocities relative to stable North America (in ITRF2008), with ellipses indicating 95\% confidence regions, corrected for GIA, postseismic, and interseismic transient motion (cf. text). The grey vector shows the Yakutat/ North America (YK/NA) motion (50.3 mm/a [Elliott et al., 2010]; NB: different scale). Black lines are locations of southern and northern velocity profiles (Figures 4 and 6). Red lines are fault systems referred to in the text-DF: Denali Fault, TF: Totschunda Fault, FF: Fairweather Fault, DRF: Duke River Fault, MF: Malaspina Fault, CF/BF: Contact and Bagley Faults, CSEF: Chugach-St. Elias Fault, and YB: Yakutat Bay. Dashed red line shows the hypothetical location of the Connector Fault from Spotila and Berger [2010].
The geological setting of the YakutatSt. Elias collision zone corresponds to the transition between the Aleutian subduction to the west and the Queen Charlotte-Fairweather transform fault to the south (Figure 1). The St. Elias orogen marks the oblique collision and partial accretion of the Yakutat microplate to the North America northern cordillera since the middle to late Miocene [Plafker et al., 1994; Bruhn et al., 2004]. In the frontal part of the orogen, the sedimentary cover of the Yakutat terrane is accreted to the cordilleran margin along an orogenic wedge [Berger et al., 2008; Bruhn et al., 2012; Chapman et al., 2012]. This crustal accretionary prism comprises numerous faults and structures whose activity remain debated and that are not directly addressed in our study; hereafter we refer to the "Chugach-St. Elias prism" to describe the overall wedge without distinctions between specific structures (Figure 1). These faults join at depth on a low-angle décollement along which the Yakutat terrane basement is underthrust beneath the cordillera [Doser, 2012; Worthington et al., 2012; Elliott et al., 2013]. The eastern region of the orogen is characterized by the presence of several major strike-slip faults (Figure 1) -the Fairweather, Denali, and Totschunda Faults—which accommodate the highly oblique Yakutat-North America motion by a combination of dextral shear and shortening [Lahr and Plafker, 1980; Plafker et al., 1994; Bruhn et al., 2004; Elliott et al., 2010]. The eastern St. Elias syntaxis area is clearly highlighted by (Figure 1) the highest topography (Mount Logan massif), the highest exhumation rates ( $5 \mathrm{~mm} / \mathrm{a}$ [Spotila and Berger, 2010]), and the transition from strike-slip to oblique fold and thrust faults.

\section{GPS Data}

\subsection{GPS Network and Data Processing}

Data from 12 new campaign GPS stations located on the Yukon side of the St. Elias Mountains are integrated with those from 23 continuous stations and 45 campaign stations distributed in eastern and southeastern Alaska, Yukon, northern British Columbia, and the Northwest Territories (Figures 2 and 3 and Table S1 in the supporting information). The data from continuous sites range from 1995 (for the oldest stations) to 2013, with an average of 8.1 years of observations per station. Campaign site surveys vary with the different networks. The oldest stations were installed in 1997, and the last survey was in 2013 (average of 6.6 years per site). In Yukon, the new GPS sites were surveyed annually between 2009 and 2013 at the same period (summer) using similar equipment (calibrated force-centered masts) for a minimum of $48 \mathrm{~h}$, in order to account for diurnal atmospheric effects and ensure robust estimates of both horizontal and vertical velocities. GPS daily positions are calculated with the PPP (Precise Point Positioning) software provided by Natural Resources Canada [Héroux and Kouba, 2001]. We use precise ephemeris, clocks, Earth orientation 
parameters, and absolute antenna phase center tables provided by the IGS (International Global Navigation Satellite Systems Service) [Dow et al., 2009]. Corrections are applied for tropospheric delays, based on VMF1 (Vienna Mapping Functions) [Boehm et al., 2006], and for ocean tide loading using the FES2004 (Finite Element Solution) model [Lyard et al., 2006]. Owing to the use of IGS precise products, daily positions are defined in the satellite reference frame, i.e., IGS05, IGS08, and IGb08 depending on the acquisition date.

Velocities for continuous and campaign stations are estimated by a least squares inversion weighted by the position uncertainties. For continuous data, the inverted model comprises a linear term (velocity), annual and semiannual sinusoids (seasonal effects), and offsets at times of antenna changes or earthquakes. For campaign data, the model comprises only a linear term. The velocities derived from this PPP processing strategy are in good agreement with the ITRF2008 reference frame, with a mean difference of $0.3 \mathrm{~mm} / \mathrm{a}$ compared to the nominal ITRF2008 velocities [Altamimi et al., 2011] at the two common sites (WHIT and INVK). The PPP solution is also validated by a comparison with a double-difference solution (Bernese 4.2) at a subset of 10 campaign stations, which indicates a mean difference of $0.5 \mathrm{~mm} / \mathrm{a}$. These differences between solutions are similar to the velocity standard deviation (cf. below) and are not significant. The velocities are shown in Figure $2 \mathrm{a}$ and given in Table $\mathrm{S} 1$ in the supporting information, relative to stable North America after correction for the rigid plate motion using the North America/ITRF2008 rotation vector [Altamimi et al., 2012].

\subsection{GPS Velocity Uncertainties}

Velocity uncertainties for continuous stations are estimated using the colored noise formulations of Williams [2003]. For each site, we estimate the spectral index and frequency spectrum amplitude to calculate a formal velocity standard error. For campaign stations, we assume a colored noise model similar to that of continuous stations and calculate the velocity uncertainties using a combination of white and flicker noise using the formulation of Mao et al. [1999]. The white and flicker component amplitudes are estimated at each campaign station using the data dispersion (root-mean-square of daily scatter) multiplied by a scaling factor calibrated at nearby continuous sites. Average velocity uncertainties are $0.3 \mathrm{~mm} / \mathrm{a}$ and $0.5 \mathrm{~mm} / \mathrm{a}$ on the horizontal and vertical components, respectively, for the continuous stations and $1.7 \mathrm{~mm} / \mathrm{a}$ and $2.9 \mathrm{~mm} / \mathrm{a}$ for the campaign stations (Figure $2 \mathrm{a}$ and Table S1 in the supporting information).

\section{Transient Corrections and Fault Velocities}

In our study area, GPS velocities are affected by three sources of transient motions: postseismic relaxation associated with the $M_{w}=7.92002$ Denali earthquake [Johnson et al., 2009]; Glacial Isostatic Adjustment (GIA), primarily in response to rapid post Little Ice Age ice retreat since the 1800s [Larsen et al., 2005]; and interseismic loading on main faults.

\subsection{Postseismic Correction}

Numerical models of postseismic deformation do not provide robust estimates for the time period and region of interest: These models are calibrated by displacement data from the early postseismic phase (2002-2005 for Freed et al. [2006] and 2002-2007 for Johnson et al. [2009]) and present an important misfit in the Wrangell-St. Elias area [Johnson et al., 2009]. Thus, we correct the GPS velocities using an empirical approach to determine the potential impact of Denali postseismic deformation. We estimate velocity variations using a 3 year sliding window on continuous time series, starting after the Denali earthquake until 2013 (cf. supporting information Text S1 and Figure S1), which allow us to define two groups of stations associated with the following corrections:

1. Stations close to the rupture $(<150 \mathrm{~km})$ : The position and velocity time series suggest a rapid decay of postseismic effect with a characteristic time of about 4-5 years. Thus, we correct for the postseismic transient by using only post-2007 data (cf. supporting information). For sites located within $\sim 50-75 \mathrm{~km}$ of the Denali Fault, significant postseismic deformation remains and steady velocities cannot yet be interpreted. For other sites, a possible postseismic effect of up to 1-2 $\mathrm{mm} / \mathrm{a}$ may remain.

2. Stations in the St. Elias Mountains and further afield (>150 km): No significant postseismic effect is visible in the 3 year velocity time series (within standard deviations of $\sim 1 \mathrm{~mm} / \mathrm{a}$, cf. supporting information), and no postseismic correction is applied, in agreement with previous estimates for this region [Leonard et al., 2007; Elliott et al., 2010]. 


\subsection{Glacial Isostatic Adjustment}

$\mathrm{Hu}$ and Freymueller [2012] provide the most recent GIA model for the region, which is an update of previous studies [Larsen et al., 2005; Elliott et al., 2010]. It is composed of an Earth model with an elastic lithosphere of $55 \mathrm{~km}$ thickness, $250 \mathrm{~km}$ thick asthenosphere with a viscosity of $3 \times 10^{19} \mathrm{Pas}$, and VM5a upper mantle structure. The ice model comprises 10 or $20 \mathrm{~km}$ diameter disks defining the ice load history interpolated and scaled from the late twentieth century ice thickness change data of Berthier et al. [2010], following the approach of Larsen et al. [2005]. The Earth model was optimized based on uplift rate observations. Berthier et al. [2010] constructed a spatially complete data set but noted that data from Alaska and Canada are difficult to unify due to different dates of the map bases; the international border is visible as an offset in the ice change rate maps. We compare the vertical velocities from the GPS data and the model prediction to evaluate the fit of the model to the newly available data from the Yukon Territory. The model underestimates the GPS vertical velocities by $\sim 3 \mathrm{~mm} / \mathrm{a}$ in the St. Elias Mountains. This misfit could be due to several factors, either related to the GIA model (Earth structure, ice history, and mass budget) or to local tectonics, which we cannot presently discriminate.

We test the effect of small modifications to the original GIA model by keeping the same Earth structure and ice history but varying the recent ice loss (last $2 \mathrm{ka}$ ) as a proxy. An increase of $30 \%$ in ice loss in the Yukon part of the St. Elias Mountains yields the best match to our GPS vertical velocities, with an average misfit of $1.4 \mathrm{~mm} / \mathrm{a}$, versus $3.1 \mathrm{~mm} / \mathrm{a}$ for the original model predictions [Hu and Freymueller, 2012]. We correct the GPS velocities using the modified model (cf. supporting information Table S1), which results in horizontal GIA corrections of $0.2-0.5 \mathrm{~mm} / \mathrm{a}$ on average, up to $3 \mathrm{~mm} / \mathrm{a}$ at sites in the southeastern Alaska - Glacier Bay area. Corrections to the vertical velocities are much larger (average of $7.5 \mathrm{~mm} / \mathrm{a}$, up to $30 \mathrm{~mm} / \mathrm{a}$ ). Although the uncertainties remain in the GIA model calibration, for this paper we are interested in the horizontal component of the GIA model calibration, which is small over most of the study area. Most horizontal velocity corrections are less than $1 \mathrm{~mm} / \mathrm{a}$ and thus have little impact on the final velocity field, for which uncertainties are correspondingly smaller. Further studies improving locally the GIA model of Hu and Freymueller [2012] are needed to better address this question.

Uncertainties associated with the postseismic and GIA corrections are difficult to assess. Detailed analyses and parameter tests would be required to provide quantitative uncertainties, which would still be constrained by the model limitations (e.g., Earth structure that does not include lateral variations in rheology). However, we can estimate first-order uncertainties on these corrections by considering extreme cases (no correction, best fit model, model modified within 50\% range, etc.). GIA horizontal corrections are small compared to the GPS velocities (Figure 2a versus Figure 2b), indicating that reasonable variations in the model will lead to corrected GPS velocities differing by less than their standard errors ( $<0.5 \mathrm{~mm} / \mathrm{a}$ on average) [Elliott et al., 2010]. A similar argument can be made for postseismic corrections in the far field $(>150 \mathrm{~km}$ from the Denali rupture), especially in southwest Yukon (i.e., within the southeastern nodal region).

\subsection{Interseismic Loading and Fault Slip Rates}

In order to discuss long-term tectonics, we need to remove the interseismic loading associated to the main active faults. Elliott et al. [2010, 2013] carried out detailed analyses of the regional interseismic deformation using block models (Figure S4 in the supporting information). Such analyses provide a useful kinematic frame but constrain the interpretation to a rotating rigid block end-member perspective [Thatcher, 2003]. In addition, the two block models were developed for separate regions and are not completely consistent on their boundaries. In order to limit the impact of the interseismic corrections on the residual strain patterns, we use simple back slip models [Savage and Burford, 1973; Savage, 1983] to correct the GPS data for first-order interseismic loading along the two main plate boundary faults (Fairweather Fault and Yakutat décollement). We use the fault geometries described by Elliott et al. [2010, 2013] and assume fully locked faults. We evaluate alternative models so that we can avoid overinterpretation of strain patterns where the elastic component of the strain field is sensitive to the details of the models.

The Fairweather-Denali system south of about $60.5^{\circ} \mathrm{N}$ presents a fairly simple case of strike-slip and shortening partitioning that can be analyzed along a fault-normal cross section (Figures 3 and 4). Fault-parallel velocity components (Figure 4a) show an eastward decrease from 49 to $0 \mathrm{~mm} / \mathrm{a}$, with an arctangent shape 


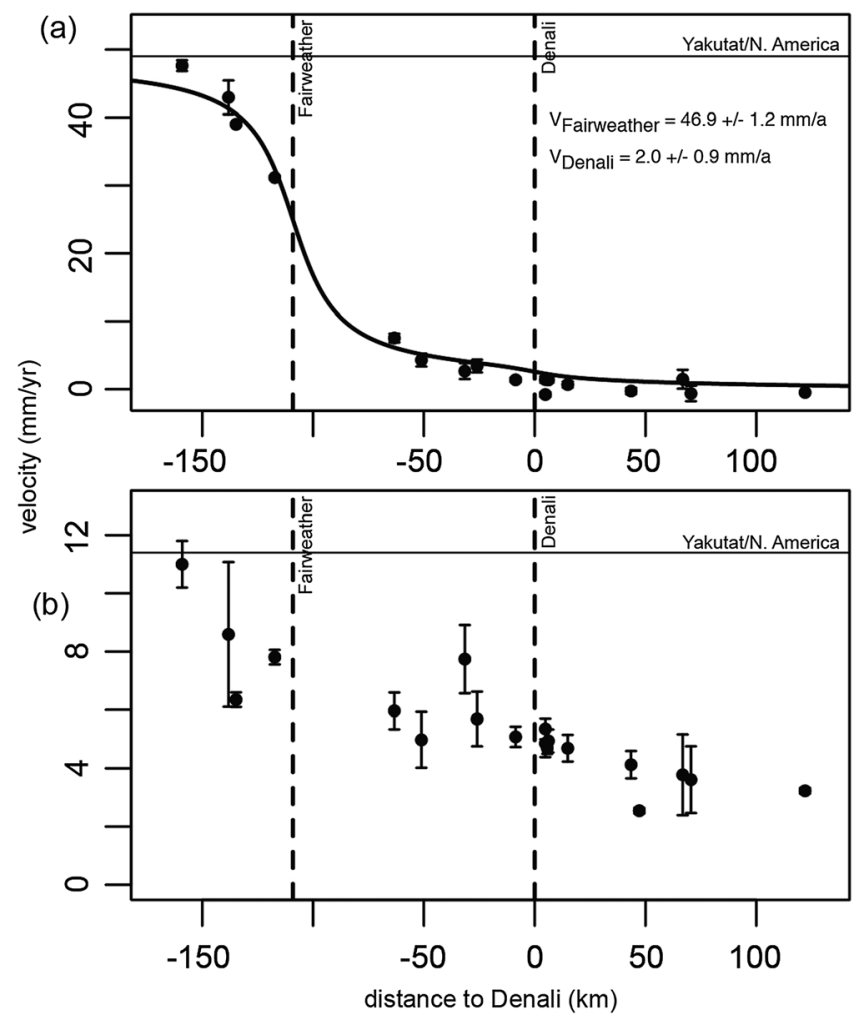

Figure 4. Southern horizontal velocity profile. (a) The fault-parallel (NE-SW) and (b) fault-normal (NW-SE) velocity components (corrected for GIA and postseismic transients). Solid circles with error bars show the GPS velocity with their standard errors projected along the profile (cf. Figure 3 for location). The solid curve in Figure 4a shows the best fit interseismic model for locked Fairweather (FF) and Denali (DF) Faults with $15 \mathrm{~km}$ locking depth (cf. text). symptomatic of interseismic loading along the Fairweather Fault. On both the Fairweather and Denali Faults, the interseismic locking depth may range between $\sim 10 \mathrm{~km}$, a commonly assumed value, and $\sim 20 \mathrm{~km}$, which corresponds to the maximum extent of microseismicity in the region [Meighan et al., 2013]. Inversion of the GPS velocities yields a slip rate for the Fairweather Fault between $52 \pm 1 \mathrm{~mm} / \mathrm{a}$ and $42 \pm 1 \mathrm{~mm} / \mathrm{a}$, depending on the assumed locking depth (20 and $10 \mathrm{~km}$, respectively). Similarly, the slip rate on the Denali Fault varies between $1 \pm 1$ and $3 \pm 1 \mathrm{~mm} / \mathrm{a}$. For our interseismic corrections, we use average slip rates of $46.9 \pm 1.2 \mathrm{~mm} / \mathrm{a}$ and $2.0 \pm 0.9 \mathrm{~mm} / \mathrm{a}$ for the Fairweather and Denali Faults, respectively, with a $15 \mathrm{~km}$ locking depth. We test the influence of this assumption, which results in less than $1 \mathrm{~mm} / \mathrm{a}$ of difference between the models (Figure S3 in the supporting information). Such a simple model does not take into account potential local rotations. The differences in slip rates between our model and the block model of Elliott et al. [2013] are of the order of 2-4 mm/a in the Chugach-St. Elias prism and less than $1 \mathrm{~mm} / \mathrm{a}$ elsewhere (Figure S4 in the supporting information). This difference in the

prism is not an issue in the scope of this paper, as we do not investigate this area in details but only consider the large-scale tectonics.

For the Yakutat décollement, Elliott et al. [2013] estimate a cumulative slip rate of about 30-40 mm/a on the numerous structures in the Chugach-St. Elias prism. Similar to the Fairweather-Denali region, we wish to correct for first-order interseismic effects without imposing strain patterns. Thus, we estimate the interseismic loading assuming a slip rate of $30 \mathrm{~mm} / \mathrm{a}$ on the Yakutat décollement and a single frontal thrust with a geometry based on Elliott et al. [2013]. We test the effect of variations of the fault geometry and slip rate on these corrections (Figure S2 in the supporting information) and find variations up to $5 \mathrm{~mm} / \mathrm{a}$ for stations near the frontal thrust and less than $\sim 3 \mathrm{~mm} / \mathrm{a}$ for stations in the far field to the north of the St. Elias Mountains. Differences between models are much smaller for sites to the east of the syntaxis.

The residual velocity field differs only slightly from the original GPS field in the far field of the principal plate boundary faults (Figure 2). The main change corresponds to a $30-50 \%$ reduction and small rotation of velocities north of the Chugach-St. Elias prism. Uncertainties in the transient corrections are negligible where the corrections are small relative to the observed velocities. The only region that does not correspond to this criterion is within and directly north of the Chugach-St. Elias prism, where interpretation of the residual GPS velocities must be done with caution due to the complex nature of the interseismic signal (see Figures S2-S4 in the supporting information for uncertainties). Hereafter, the results and interpretations are based on the velocities corrected for the transient motions (postseismic, GIA, and interseismic) described above. We focus our interpretations on the regions where the elastic deformation corrections are not sensitive to the details of the models assumed for them. 


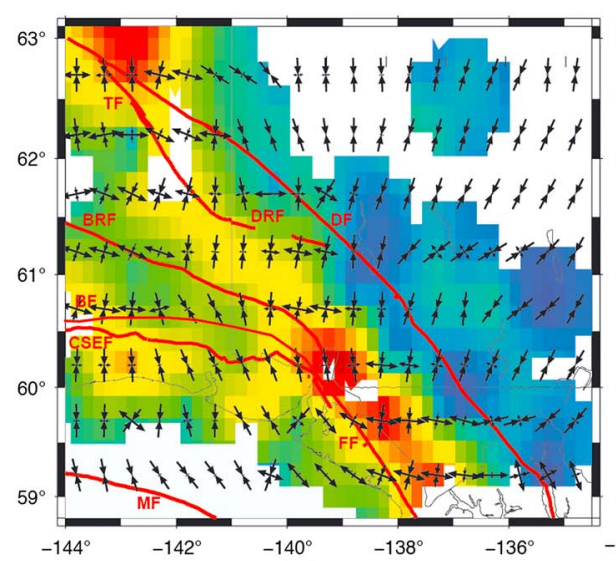

(a)

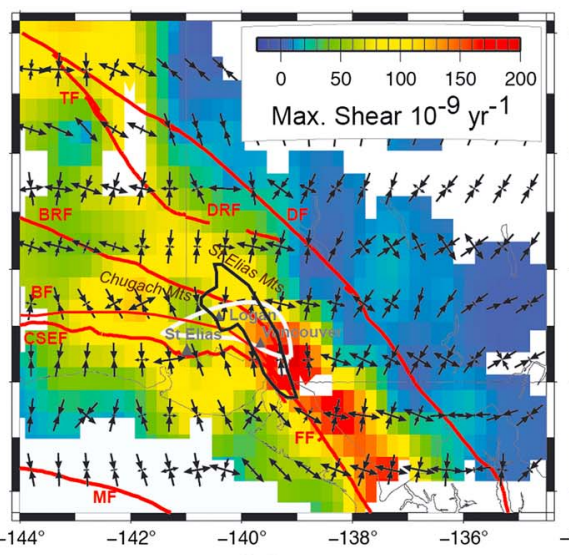

(b)
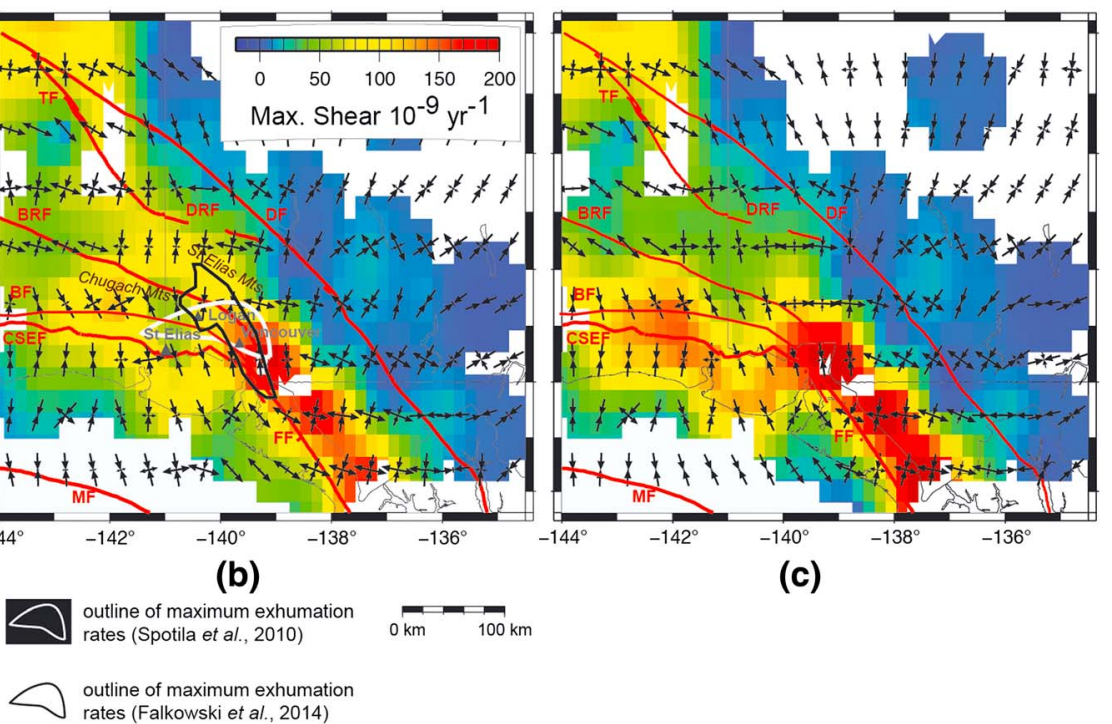

(c)

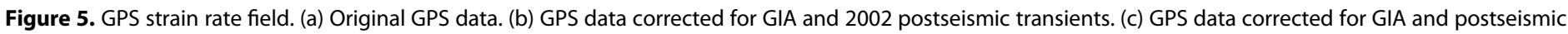

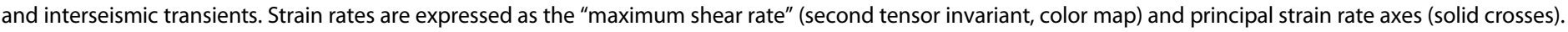
Red lines show main faults and fault system (cf. Figure 1).

\section{Indentor Corner}

\subsection{Kinematics}

The residual GPS velocity field highlights three main kinematic domains across the syntaxis (Figure 3):

1. Southeast of the syntaxis, GPS velocities show a strong rotation of orientations from fault-parallel near the Fairweather Fault to fault-normal along the southern Denali Fault.

2. West of the Yukon-Alaska border, the frontal part of the orogen is characterized by velocities nearly parallel to the Yakutat/North America motion that decrease from 35 to $40 \mathrm{~mm} / \mathrm{a}$ along the coast to $10-15 \mathrm{~mm} / \mathrm{a}$ in the Chugach Mountains.

3. In the Yukon sector of the St. Elias Mountains, our new GPS data show a rapid decrease to 5-10 mm/a associated with a strong rotation of velocity orientations from about $\mathrm{N} 25^{\circ} \mathrm{W}$ in the northwest to $\mathrm{N} 50^{\circ} \mathrm{E}$ in the southeast, i.e., from nearly parallel to nearly orthogonal to the Yakutat/North America motion.

In contrast to the fault-parallel component, the fault-normal velocity components in the Fairweather-Denali system indicate a gradual eastward decrease (Figure $4 \mathrm{~b}$ ) and distributed shortening with no clear strain localization. This region thus presents strong strain partitioning, with approximately one third of the Yakutat-North America fault-normal motion transmitted east of the Denali Fault to the central part of the Yukon Cordillera, whereas nearly all of the fault-parallel motion is accommodated on the Fairweather Fault, leaving the southern Denali Fault mainly inactive. The strong rotation of GPS velocities in the syntaxis area corresponds to a fan-shaped structure with flow lines radiating away from central region, roughly the Mount Logan massif, typical of the kinematic pattern expected for an indentor corner (e.g., east Himalaya syntaxis [Tapponnier and Molnar, 1976; Shen et al., 2005]).

\subsection{Strain Rates}

On the basis of the different velocity fields, we derive regional strain rate fields using an adaptive interpolation scheme with a smoothing length ranging between 40 and $100 \mathrm{~km}$, depending on the GPS site density [Mazzotti et al., 2011]. The resulting strain rate fields (original and corrected data) are represented in Figure 5 as the maximum shear rate (second invariant) and principal axes. Hereafter, we focus on the strain rates derived from the corrected velocity field (Figure $5 \mathrm{c}$ and see Text S3 in the supporting information for a detailed description of the differences between the strain rate fields). Average spacing between GPS sites is $\sim 40 \mathrm{~km}$, with two areas of slightly lower density north of Yakutat Bay and within the eastern Chugach Mountains 
(Figure 1). As a result, the location of strain rate features is only defined with $20-30 \mathrm{~km}$ resolution.Several main features can be identified in the strain rate field (Figure $5 \mathrm{c}$ ):

1. The peak in strain rates $\left(\sim 200 \times 10^{-9} \mathrm{a}^{-1}\right)$ is located in the syntaxis, at the junction between the Fairweather Fault, Chugach-St. Elias prism, and Border Range Fault, $\sim 50 \mathrm{~km}$ southeast of the Mount Logan massif.

2. Similar to the velocity orientations, principal strain rates rotate around the syntaxis. Maximum shortening axes $\left(\varepsilon_{1}\right)$ are oriented N-S west of the syntax and turn NE-SW to the southeast.

3. The strain rate style is primarily shortening across the frontal part of the Chugach orogen up to the junction with the Fairweather Fault at the tip of Yakutat Bay, in agreement with stress patterns from seismicity [Ruppert, 2008].

4. North of the syntaxis, between the Border Range, Totschunda, and Duke River Faults, strain rates are low, with a rapid lateral variation from N-S shortening to E-W extension. This extensional signal is in part related to the interseismic correction (cf. Figures 2 and 5) and should be interpreted with caution.

These GPS strain rate features are in agreement with the deformation patterns expected at the corner of an indentor or an underthrusting plate. On the basis of analog models of oblique collision, Rosenberg et al. [2007] show that the deformation at the tip and edge of an indentor is very sensitive to the convergence obliquity. However, all oblique convergence models result in a strong rotation of the shortening axis around the indentor corner, with limited extension perpendicular to the convergence in front of the syntaxis, similar to our observed strain rate field. Rosenberg et al. [2007] argue that the convergence-normal extension is required to accommodate variations in shortening around the syntaxis that result from the system geometry (in our case, a change from N-S to NE-SW shortening). These particular kinematic and strain conditions at the syntaxis are also observed in numerical models of Yakutat underthrusting and collision by Koons et al. [2010], who term this region of high deformation a "strain knot." Deformation patterns predicted by these numerical experiments are similar to those observed in our GPS data: convergenceparallel shortening dominates in the Chugach-St. Elias prism, and a mix of dextral shear and convergencenormal shortening occur in the syntaxis and Fairweather-Denali transpressive system. The junction between these two domains corresponds to a strain knot, characterized by focused, high strain rates and abruptly rotating shortening directions (Figure $5 \mathrm{c}$ ).

\section{Discussion}

\subsection{Syntaxis and Strain Knot}

Our GPS observations complement recent lines of evidence that point to the existence of a region of focused deformation at the syntaxis. (1) The earthquake distribution shows a small concentration at the tip and northwest of Yakutat Bay [Doser, 2012, 2014]. Statistical summation of the seismicity yields $10-40 \mathrm{~mm} / \mathrm{a}$ of shortening and transpressive dextral shear [Leonard et al., 2008]. This region is also the location of the two $M_{w} \sim 81899$ earthquakes, which accommodated roughly NE-SW oblique shortening [Plafker and Thatcher, 2008]. (2) Thermochronology data from low- and medium-temperature markers indicate a localized zone of intense exhumation located north-northwest of Yakutat Bay [Enkelmann et al., 2009; Falkowski et al., 2014; Spotila and Berger, 2010] (Figure 5c). Although the extent and nature of the exhumation peak is debated, thermochronology data show that the region between Yakutat Bay and the Mount Logan massif has experienced several kilometers of additional uplift compared to the rest of the orogen to the west and southeast since the middle to late Miocene. (3) The region north and northwest of Yakutat Bay corresponds to a major structural bend in the plate boundary fault system and topographic orientations, with $35-40^{\circ}$ rotation between the Fairweather Fault to the southeast and the Chugach-St. Elias prism to the west [Bruhn et al., 2012]. This tectonics bend is associated with the highest topography outside of the Mount Logan massif (Mount Saint Elias and Vancouver) (Figures 1 and 5).

The exact location of these various strain knot indicators do not exactly agree. The peak in GPS strain rates is located at the northern termination of the Fairweather Fault, north-northeast of Yakutat Bay (Figure 5c), $\sim 50 \mathrm{~km}$ southeast of the exhumation peak defined by zircon fission track data [Falkowski et al., 2014; Enkelmann et al., 2009], and within but slightly offset to the southeast compared to the high exhumation zone defined by low-temperature thermochronology data [Spotila and Berger, 2010] (Figure 5c). The GPS strain peak is also shifted southeast compared to the highest topography (Mount Logan massif). These small offsets may be the result of location biases in the various data sets. In particular, the GPS station 


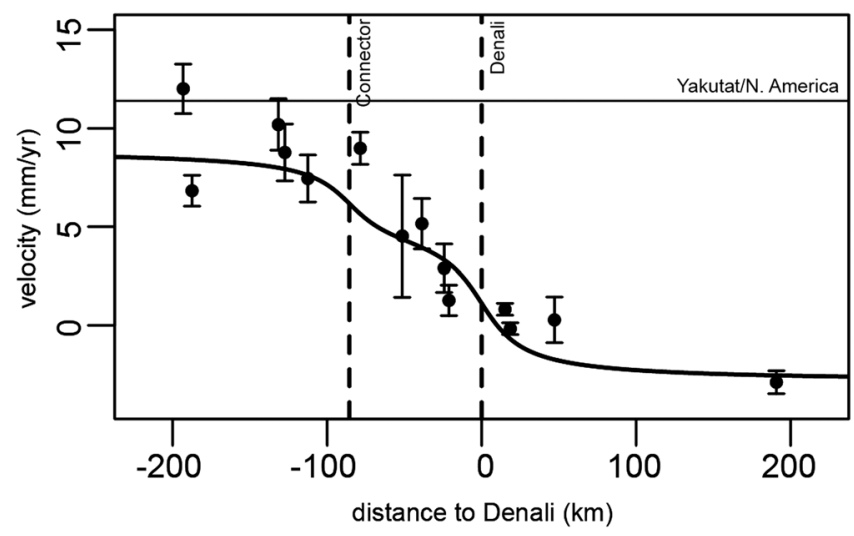

Figure 6. Northern horizontal velocity profile. Solid circles with error bars show the fault-parallel (NE-SW) GPS velocity components (corrected for GIA and postseismic transients) with their standard errors projected along the profile (cf. Figure 3 for location). The solid curve shows the best fit interseismic model for locked Connector (CF) and Denali (DF) Faults with $15 \mathrm{~km}$ locking depth (cf. text).

between the Chugach-St. Elias prism and the Denali Fault (Figures 1 and 5). Fan-like velocities at the front of the syntaxis result in relatively low strain rates $\left(\sim 50 \times 10^{-9} \mathrm{a}^{-1}\right)$ and complex lateral variations between $\mathrm{N}-\mathrm{S}$ shortening and E-W to SE-NW extension, with limited indications of significant shear or strike-slip deformation (Figure $5 \mathrm{c}$ ). In this area, a hypothetical structure (the Connector Fault) has been proposed to link the Fairweather and Totschunda Faults, with tentative support from kinematic models [Lahr and Plafker, 1980], thermochronology [Spotila and Berger, 2010], and seismicity data [Doser, 2014]. We test the possible presence of this fault using GPS data along a NE-SW profile (Figure 6, cf. Figure 3 for location). Fault-parallel velocities across this region show a clear northeastward decrease from $\sim 10$ to $\sim 0 \mathrm{~mm} / \mathrm{a}$, but no clear indication of localized deformation associated with creeping or locked faults. Attempting to fit an interseismic model [Savage and Burford, 1973; Savage, 1983] of locked Connector and Denali Faults to the GPS data yields a poor data fit (average misfit of $1.3 \mathrm{~mm} / \mathrm{a}$ ), with right-lateral slip rates of $4 \pm 2 \mathrm{~mm} / \mathrm{a}$ and 7 $\pm 2 \mathrm{~mm} / \mathrm{a}$ for the best fit model for the two faults, respectively (imposed locking depth of $15 \mathrm{~km}$ ). In particular, the GPS station located directly east of the hypothetical Connector Fault trace shows the same velocity as those to the west $(\sim 10 \mathrm{~mm} / \mathrm{a}$, Figure 6$)$, indicating that no significant strike-slip motion occurs within this region. The highest shear appears to be located east of the Connector Fault and corresponds to the clockwise rotation of velocities around the indentor corner (Figure 3). Considering the low density of GPS sites in the area and the continuous gradient observed southwest of the Denali Fault, our data cannot resolve the fault location more precisely although they would be consistent with a fault shifted lightly northeast of the proposed Connector Fault.

The Yakutat collision may be associated with deformation of the Cordillera further inland, as far as the foreland belt $500-800 \mathrm{~km}$ to the north and east. Concentration of seismicity in these regions [Leonard et al., 2008] and numerical models of strain transfer [Mazzotti and Hyndman, 2002; Soofi and Wu, 2008] suggest that as much as $5 \mathrm{~mm} / \mathrm{a}$ of residual deformation may be transmitted to the Alaska-Yukon Cordillera. Our new GPS solution indicates that sites in central and eastern Yukon are associated with raw velocities (not corrected for transient motions) of $2-3 \mathrm{~mm} / \mathrm{a}$ to the southeast (supporting information Table S1). The interpretation of these small velocities is strongly sensitive to reference frame and transient (GIA) corrections. Relative to the two stations on the east side of the Cordillera, stations in central and northern Yukon indicate $1-2.5 \mathrm{~mm} / \mathrm{a}$ differential motion oriented northeast to southeast, depending on assumed GIA corrections. These rates suggest that far-field strain transfer in the cordillera may be more limited than previously proposed.

\subsection{Indentor-Corner-Distributed Tectonics}

Figure 7 presents a schematic view of regional tectonics associated with the Yakutat collision and its eastern syntaxis. In the central (western) part of the collision, most of the Yakutat/North America convergence is 


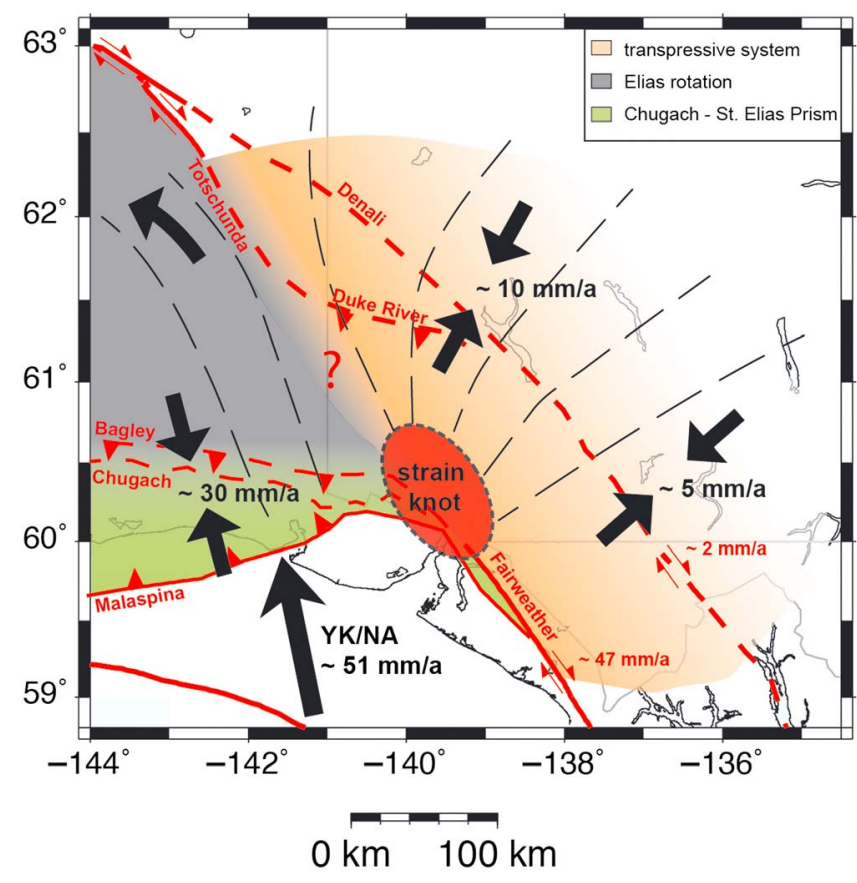

Figure 7. Schematic model of present-day indentor-corner tectonics. The syntaxis region is divided in three main domains. Green: Chugach-St. Elias prism; orange: Fairweather-Denali transpressive system; grey: zone of counterclockwise rotation. Thin dashed lines show the regional pattern of displacements and maximum horizontal shortening rotating around the strain knot. Black facing arrows indicate shortening orientations with approximate shortening rates across the main domains. Solid and dashed red lines show main and potentially active faults, respectively. accommodated within the Chugach-St. Elias prism [Chapman et al., 2012; Elliott et al., 2013], although inland strain transfer and counterclockwise rotation between the prism and the Denali Fault may account for $\sim 20-25 \%$ of the Yakutat-North America convergence [Leonard et al., 2007; Elliott et al., 2013]. The area between the ChugachSt. Elias prism and the central Denali Fault is characterized by relatively low strain rates (Figure $5 c$ ), consistent with the predicted separation of these two deformation zones in response to Yakutat microplate underthrusting [Koons et al., 2010].

The lateral (eastern) part of the collision zone (Fairweather-southern Denali system) is characterized by a sharp rotation of velocity and strain rate orientations, which become nearly orthogonal to the Yakutat-North America convergence in SW Yukon. We infer that this rotation pattern marks the transition from frontal collision in the prism to transpression [Koons et al., 2010], in response to strain concentration in the syntaxis/strain knot area. As shown in Figure 7, this velocity and strain rate rotation results in fault-normal shortening along the southern section of the Denali Fault, resulting in very low $(2.0 \pm 0.9 \mathrm{~mm} / \mathrm{a})$ dextral slip rate (Figure 4a) and potentially active shortening structures [Haeussler et al., 2013].

These results suggest two different tectonic regimes in SE Alaska and SW Yukon, in response to the Yakutat collision. In the region directly in front and east of the syntaxis, the velocity and strain rate patterns appear to be best matched by diffuse deformation and do not fit previous models of large active faults and rigid blocks (e.g., Fairweather block limited by active Connector and Eastern Denali Faults [Elliott et al., 2010]). In contrast, significant Holocene slip rates on the central Denali Fault $(\sim 12 \mathrm{~mm} / \mathrm{a})$ and the Totschunda and Denali Faults at their northern junction ( $\sim 6$ and $\sim 8 \mathrm{~mm} / \mathrm{a}$ [Matmon et al., 2006]) suggest that these structures accommodate most of the deformation in the northern part of the orogen. Within this tentative tectonic schema (Figure 7), strain transfer from the syntaxis to the upper plate interior is accommodated by a combination of diffuse deformation (e.g., between the Fairweather and northern Totschunda Faults) and localized deformation on major active faults (e.g., central Denali Fault).

\section{Conclusion}

Our GPS data and analysis provide new constraints on the present-day tectonics of the Yakutat-St. Elias collision, particularly its eastern syntaxis. The residual (long-term) GPS velocities show a strong rotation around the syntaxis, from nearly parallel to the plate motion west of the syntaxis to nearly orthogonal east of it, over less than $100 \mathrm{~km}$ distances. This velocity rotation is associated with a narrow zone $(50-100 \mathrm{~km})$ of focused deformation at the syntaxis with high strain rates and a rapid rotation of the maximum shortening axis orientations. These patterns, consistent with that expected at an indentor corner, result in a fan-shaped inland strain transfer into the Yukon and SE Alaska cordillera where it interacts with inherited structures to produce a strong lateral variation in strain localization and fault activity: (1) The Denali Fault changes from $\sim 12 \mathrm{~mm} / \mathrm{a}$ nearly pure strike slip in central Alaska to, potentially, a few $\mathrm{mm} / \mathrm{a}$ of shortening 
in SE Yukon; (2) diffuse E-W transtension seems to characterize the St. Elias Mountains in front of the syntaxis, with no evidence for localization on the hypothetical Connector Fault.

This tectonic diagram raises several questions on the detailed strain distribution, fault activity, and dynamics of the orogen. In order to better understand the spatial variations in regional strain distribution and partitioning, the relationship between the indentor-corner dynamics and inherited structures needs to be analyzed in detail. The eastern Yakutat syntaxis region is marked by two large lithospheric-scale faults (Fairweather and Denali) that accommodated several hundred kilometers of displacements and, as a result, likely correspond to zones of weakness, albeit with potentially strong along-strike anisotropy [Rasendra et al., 2014]. Other large faults and terrane boundaries such as the Duke River, Totschunda, or Chugach-St. Elias prism faults may be more limited and only affect the upper crust, although they might mark lateral differences in crustal composition and rheology. New studies including 3-D numerical modeling, geomorphological mapping, and dating along the Denali and Totschunda fault systems are required to better understand the interactions between the Yakutat collision dynamics and these various structures.

\section{Acknowledgments}

The GPS data used in this paper are available from Natural Resources Canada "Canadian Crustal Deformation Service" (contact: Yuan.Lu@NRCan-RNCan.gc.ca) and the UNAVCO Data Archive (http:// www.unavco.org/data/gps-gnss/gps-gnss. html). Figures are done using the GMT (http://gmt.soest.hawaii.edu) and R (http:// www.r-project.org) software. We thank Yan Hu for providing his GIA model. We thank Ray Wells, Mike Floyd, and the Associate Editor for their constructive reviews. This work was supported by NSERC Discovery grant 356443-2008 and Agence National de la Recherche grant ANR-12-CHEX-0004-01.

\section{References}

Altamimi, Z., X. Collilieux, and L. Métivier (2011), ITRF2008: An improved solution of the International Terrestrial Reference Frame, J. Geod., 85(8), 457-473, doi:10.1007/s00190-011-0444-4

Altamimi, Z., L. Métivier, and X. Collilieux (2012), ITRF2008 plate motion model, J. Geophys. Res., 117, B07402, doi:10.1029/2011JB008930.

Berger, A. L., J. A. Spotila, J. B. Chapman, T. L. Pavlis, E. Enkelmann, N. A. Ruppert, and J. T. Buscher (2008), Architecture, kinematics, and exhumation of a convergent orogenic wedge: A thermochronological investigation of tectonic-climatic interactions within the central St. Elias orogen, Alaska, Earth Planet. Sci. Lett., 270(1-2), 13-24, doi:10.1016/j.epsl.2008.02.034.

Berthier, E., E. Schiefer, G. K. C. Clarke, B. Menounos, and F. Rémy (2010), Contribution of Alaskan glaciers to sea-level rise derived from satellite imagery, Nature Geosci., 3, 92-95, doi:10.1038/NGEO737.

Boehm, J., B. Werl, and H. Schuh (2006), Troposphere mapping functions for GPS and very long baseline interferometry from European Centre for Medium-Range Weather Forecasts operational analysis data, J. Geophys. Res., 111, B02406, doi:10.1029/2005JB003629.

Bruhn, R. L., T. L. Pavlis, G. Plafker, and L. Serpa (2004), Deformation during terrane accretion in the Saint Elias orogen, Alaska, Geol. Soc. Am. Bull., 116(7), 771-787, doi:10.1130/B25182.1.

Bruhn, R. L., J. Sauber, M. M. Cotton, T. L. Pavlis, E. Burgess, N. A. Ruppert, and R. R. Forster (2012), Plate margin deformation and active tectonics along the northern edge of the Yakutat Terrane in the Saint Elias Orogen, Alaska, and Yukon, Canada, Geosphere, 8(6), 1384-1407, doi:10.1130/GES00807.S4.

Chapman, J. B., T. L. Pavlis, R. L. Bruhn, L. L. Worthington, S. P. S. Gulick, and A. L. Berger (2012), Structural relationships in the eastern syntaxis of the St. Elias orogen, Alaska, Geosphere, 8(1), 105-126, doi:10.1130/GES00677.1.

Doser, D. I. (2012), Revisiting the 1979 St. Elias, Alaska, aftershock sequence and its regional significance, Bull. Seismol. Soc. Am., 102(6), 2392-2404, doi:10.1785/0120120007.

Doser, D. I. (2014), Seismicity of Southwestern Yukon, Canada, and its relation to slip transfer between the Fairweather and Denali fault systems, Tectonophysics, 611(C), 121-129, doi:10.1016/j.tecto.2013.11.018.

Dow, J. M., R. E. Neilan, and C. Rizos (2009), The International GNSS Service in a changing landscape of Global Navigation Satellite Systems, J. Geod., 83(3-4), 191-198, doi:10.1007/s00190-008-0300-3.

Elliott, J. L., C. F. Larsen, J. T. Freymueller, and R. J. Motyka (2010), Tectonic block motion and Glacial Isostatic Adjustment in southeast Alaska and adjacent Canada constrained by GPS measurements, J. Geophys. Res., 115, B09407, doi:10.1029/2009JB007139.

Elliott, J. L., J. T. Freymueller, and C. F. Larsen (2013), Active tectonics of the St. Elias orogen, Alaska, observed with GPS measurements, J. Geophys. Res. Solid Earth, 118, 5625-5642, doi:10.1002/jgrb.50341.

Enkelmann, E., P. K. Zeitler, T. L. Pavlis, J. I. Garver, and K. D. Ridgway (2009), Intense localized rock uplift and erosion in the St Elias orogen of Alaska, Nat. Geosci., 2(5), 360-363, doi:10.1038/ngeo502.

Falkowski, S., E. Enkelmann, and T. A. Ehlers (2014), Constraining the area of rapid and deep-seated exhumation at the St. Elias syntaxis, Southeast Alaska, with detrital zircon fission-track analysis, Tectonics, 33, 507-616, doi:10.1002/2013TC003408.

Finzel, E. S., L. M. Flesch, and K. D. Ridgway (2014), Present-day geodynamics of the northern North American Cordillera, Earth Planet. Sci. Lett., 404(C), 111-123, doi:10.1016/j.epsl.2014.07.024.

Freed, A. M., R. Bürgmann, E. Calais, J. T. Freymueller, and S. Hreinsdóttir (2006), Implications of deformation following the 2002 Denali, Alaska, earthquake for postseismic relaxation processes and lithospheric rheology, J. Geophys. Res., 111, B01401, doi:10.1029/2005JB003894.

Haeussler, P. J., P. Lipovsky, E. E. Thoms, and R. L. Wesson (2013), The Decoeli Mountain Fault, a newly identified active thrust (?) in the southwest Yukon Territory, Canada, Seismol. Res. Lett., 84(2), pp. 378, Seismol. Soc. Am. Annual Meeting abstract, Salt Lake City, Utah.

Héroux, P., and J. Kouba (2001), GPS Precise Point Positioning using IGS orbit products, Phys. Chem. Earth (A), 26(6-8), 573-578.

Holt, W. E., J. F. Ni, T. C. Wallace, and A. J. Haines (1991), The active tectonics of the eastern Himalayan syntaxis, J. Geophys. Res., 96(B9), 14,595-14,632, doi:10.1029/91JB01021.

Hu, Y., and J. T. Freymueller (2012), Geodetic observations of Glacial Isostatic Adjustment in Southeast Alaska and its implication of Earth rheology, Abstract G21A-0872 presented at 2012 Fall Meeting, AGU, San Francisco, Calif.

Johnson, K. M., R. Bürgmann, and J. T. Freymueller (2009), Coupled afterslip and viscoelastic flow following the 2002 Denali Fault, Alaska earthquake, Geophys. J. Int., 176(3), 670-682, doi:10.1111/j.1365-246X.2008.04029.x.

Koons, P. O., B. P. Hooks, T. L. Pavlis, P. Upton, and A. D. Barker (2010), Three-dimensional mechanics of Yakutat convergence in the southern Alaskan plate corner, Tectonics, 29, TC4008, doi:10.1029/2009TC002463.

Lahr, J. C., and G. Plafker (1980), Holocene Pacific-North American plate interaction in southern Alaska: Implications for the Yakataga seismic gap, Geology, 8(10), 483, doi:10.1130/0091-7613.

Larsen, C. F., R. J. Motyka, J. T. Freymueller, K. A. Echelmeyer, and E. R. Ivins (2005), Rapid viscoelastic uplift in Southeast Alaska caused by post-Little Ice Age glacial retreat, Earth Planet. Sci. Lett., 237(3-4), 548-560, doi:10.1016/j.epsl.2005.06.032. 
Leonard, L. J., R. D. Hyndman, S. Mazzotti, L. Nykolaishen, M. Schmidt, and S. Hippchen (2007), Current deformation in the northern Canadian Cordillera inferred from GPS measurements, J. Geophys. Res., 112, B11401, doi:10.1029/2007JB005061.

Leonard, L. J., S. Mazzotti, and R. D. Hyndman (2008), Deformation rates estimated from earthquakes in the northern Cordillera of Canada and eastern Alaska, J. Geophys. Res., 113, B08406, doi:10.1029/2007JB005456.

Lyard, F., F. Lefevre, T. Letellier, and O. Francis (2006), Modelling the global ocean tides: Modern insights from FES2004, Ocean Dyn., 56(5-6), 394-415, doi:10.1007/s10236-006-0086-X.

Mao, A., C. G. A. Harrison, and T. H. Dixon (1999), Noise in GPS coordinate time series, J. Geophys. Res., 104(B2), 2797-2816, doi:10.1029/1998JB900033.

Matmon, A., D. P. Schwartz, P. J. Haeussler, R. Finkel, J. J. Lienkaemper, H. D. Stenner, and T. E. Dawson (2006), Denali fault slip rates and Holocene-late Pleistocene kinematics of central Alaska, Geology, 34(8), 645-648, doi:10.1130/G22361.1.

Mazzotti, S., and R. D. Hyndman (2002), Yakutat collision and strain transfer across the northern Canadian Cordillera, Geology, 30(6), 496-498

Mazzotti, S., L. J. Leonard, R. D. Hyndman, and J. F. Cassidy (2008), Tectonics, dynamics, and seismic hazard in the Canada-Alaska Cordillera, in Active Tectonics and Seismic Potential of Alaska, Geophys. Monogr. Ser., vol. 179, edited by J. T. Freymueller et al., pp. 297-319, AGU, Washington, D. C.

Mazzotti, S., L. J. Leonard, J. F. Cassidy, G. C. Rogers, and S. Halchuk (2011), Seismic hazard in western Canada from GPS strain rates versus earthquake catalog, J. Geophys. Res., 116, B12310, doi:10.1029/2011JB008213.

Meighan, L. N., J. F. Cassidy, S. Mazzotti, and G. L. Pavlis (2013), Microseismicity and tectonics of Southwest Yukon Territory, Canada, using a local dense seismic array, Bull. Seismol. Soc. Am., 103(6), 1-6, doi:10.1785/0120130068.

Pavlis, T. L., E. Enkelmann, S. P. S. Gulick, and G. L. Pavlis (2014), Introduction: Neogene tectonics and climate-tectonic interactions in the southern Alaskan orogen themed issue, Geosphere, 10(3), 424-427.

Plafker, G., and W. Thatcher (2008), Geological and geophysical evaluation of the mechanisms of the Great 1899 Yakutat Bay Earthquakes, in Active Tectonics and Seismic Potential of Alaska, vol. 179, edited by J. T. Freymueller et al., pp. 215-236, AGU, Washington, D. C.

Plafker, G., J. C. Moore, and G. R. Winkler (1994), in Geology of the Southern Alaska Margin, vol. G-1, edited by G. Plafker and H. C. Berg, pp. 389-448, Geol. Soc. of Am., Boulder, Colo.

Rasendra, N., M. Bonnin, S. Mazzotti, and C. Tiberi (2014), Crustal and upper-mantle anisotropy related to fossilized transpression fabric along the Denali Fault, northern Canadian Cordillera, Bull. Seismol. Soc. Am., 104(4), 1964-1975.

Rosenberg, C. L., J.-P. Brun, F. Cagnard, and D. Gapais (2007), Oblique indentation in the Eastern Alps: Insights from laboratory experiments, Tectonics, 26, TC2003, doi:10.1029/2006TC001960.

Ruppert, N. A. (2008), Stress map for Alaska from earthquake focal mechanisms, in Active Tectonics and Seismic Potential of Alaska, vol. 179, edited by J. T. Freymueller et al., pp. 351-367, AGU, Washington, D. C.

Savage, J. C. (1983), A dislocation model of strain accumulation and release at a subduction zone, J. Geophys. Res., 88(B6), 4984-4996, doi:10.1029/JB088iB06p04984.

Savage, J. C., and R. O. Burford (1973), Geodetic determination of relative plate motion in central California, J. Geophys. Res., 78(5), 832-845, doi:10.1029/JB078i005p00832.

Shen, Z.-K., J. Lü, M. Wang, and R. Bürgmann (2005), Contemporary crustal deformation around the southeast borderland of the Tibetan Plateau, J. Geophys. Res., 110, B11409, doi:10.1029/2004JB003421.

Soofi, M. A., and P. Wu (2008), Crustal deformation due to Alaska-Yakutat collision, J. Geodyn., 46(1-2), 38-47, doi:10.1016/j.jog.2008.04.006.

Spotila, J. A., and A. L. Berger (2010), Exhumation at orogenic indentor corners under long-term glacial conditions: Example of the St. Elias orogen, Southern Alaska, Tectonophysics, 490(3-4), 241-256, doi:10.1016/j.tecto.2010.05.015.

Tapponnier, P., and P. Molnar (1976), Slip-lines field theory and large-scale continental tectonics, Nature, 264(5584), 319-324.

Thatcher, W. (2003), GPS constraints on the kinematics of continental deformation, Int. Geol. Rev., 45, 191-212.

Williams, S. D. P. (2003), The effect of coloured noise on the uncertainties of rates estimated from geodetic time series, J. Geod., 76(9-10), 483-494, doi:10.1007/s00190-002-0283-4.

Worthington, L. L., H. Van Avendonk, S. P. S. Gulick, G. L. Christeson, and T. L. Pavlis (2012), Crustal structure of the Yakutat terrane and the evolution of subduction and collision in southern Alaska, J. Geophys. Res., 117, B01102, doi:10.1029/2011JB008493.

Zeitler, P. K., A. S. Meltzer, P. O. Koons, D. Craw, and B. Hallet (2001), Erosion, Himalayan geodynamics, and the geomorphology of metamorphism, Geol. Soc. Am., 11, 4-8. 